\title{
Applied Anthropology, the State and Ethnic Groups in Mexico in the Twenty-first Century ${ }^{i}$
}

\author{
Salomón Nahmad \\ Center for Research and Higher Studies in Social Anthropology, Mexico
}

Copyright $(2016$ by authors, all rights reserved. Authors agree that this article remains permanently open access under the terms of the Creative Commons Attribution License 4.0 International License

\begin{abstract}
Accessing anthropological knowledge is considered as a social issue. The twenty-first century is an opportune moment to critically review the history of applied social anthropology in Mexico in the context of Latin American histories and societies. From its origins in the state, through radical critiques, and, most importantly, the entry of indigenous peoples as protagonists and producers of anthropological knowledge in the context of their political demands, anthropology is now faced with an opportunity to reformulate itself as an agent of change in order to build the anthropology of the twenty first century.
\end{abstract}

Keywords Applied Anthropology, Mexico, Indigenous Peoples, Latin America

\section{The Anthropological Perspective}

For many years, anthropologists in Mexico believed that it was enough to generate knowledge. However, anthropologists and others have questioned the legitimacy of "pure," self-contained, and "impartial" science. Social and applied anthropology has studied, and come to serve, the dispossessed, pursued, repressed and excluded members of society. Reconstructed histories, racialized and nationalistic doctrines have been written according to the social necessities of hegemonic groups, to the detriment of original peoples. As Nadel [1] describes it: "A science that could be thus abused must no longer hope to recover its spurious detachment. It will find redemption only in closeness to the problems of our existence as society and civilization" (1942:vi). Today western social and cultural anthropology is in a crisis of identity, especially as we propose more revolutionary models (García Mora and Medina [2, 3], 1983 and 1986). And this is especially when the "subjects" of anthropological research appropriate the discipline.

Intellectuals and philosophers from ethnic groups have recovered their histories in many non-Western countries, especially in Africa and South America. Examples include the writings of Kenyan anthropologist Ali A. Mazrui [4],
(1986), Maxwell Owusu [5] (1989) of Ghana, Domingo Antun [6] (1979) of Ecuador's Shuar peoples, Peruvian anthropologist Estefano Varese [7] (1979), or the eminent Brazilian anthropologist, Darcy Riveiro [8] (1995), among others. These anthropologists, coming out of indigenous peoples' organizations, have radically altered the position of subject ("the other") in anthropology and ethnology in particular, and, in general, have transformed the study of contemporary indigenous languages. These transformations must, of necessity, come from groups of native speakers themselves and then move into wider academic and intellectual communities.

Anthropology's effectiveness outside of academe has never been enough to decolonize knowledge that, until now, has supported the maintenance of asymmetrical and colonized social relations between the dominant Mexican society and indigenous peoples. Socio-cultural anthropology is unique in its careful ethnographic descriptions gives us insights about culture, political power and economic systems, especially among different cultures, especially in terms of asymmetrical power relations, exploitation, poverty, political exclusion and social discrimination.

\section{Anthropology in Latin American Political Movements}

Indigenous peoples, and their anthropologists, in Latin America continue to struggle for recognition of their rights, and are often supported by anthropologists. They and Latin American anthropologists in general, have responded to the Sandinista revolution in Nicaragua, as well as to the Zapatista movement in Chiapas, Mexico.

Indigenous anthropology, while not yet a major force, is a voice in Latin America: The meetings of Latin American anthropologists in Barbados in 1971, 1977 and 1995_-including Darcy Ribeiro y Mercio Gomes [8] (1995), Guillermo Bonfil [9] (1995), Stefano Varese [7] (1995), Miguel Bartolomé [10] (1995), George Grünberg [11] (1995), Alicia Barabas [12] (1995), Nelly Arvelo-Jiménez [13] (1995), Esteban Emilio Mosonyi [14] (1995), Silvio 
Coelho dos Santos [15] (1995), Joao Pacheco de Oliveira [16] (1995), Víctor Daniel Bonilla [17] (1995), Alberto Chirif [18] (1995), and more-built a new paradigm that replaced the assimilationist approach of Inter American indigenous congresses that did not contemplate an indigenous political strategy. Along these same lines, Jaulin's (1973) work on ethnocide was a critique of old guard integrationist (assimilationist) anthropology.

The Sandinista Revolution in Nicaragua ignited the debate about cultural autonomy, on the one hand, and the need to create a homogeneous, socialist state with a revolutionary proletariat. Mexican anthropologists participated in, and supported, Miskito ethnic groups' demands for autonomy and resistance to the Sandinista national project (see Díaz Polanco 1993) [20].

In the 1990s, the crisis brought about by the armed resistance of the National Liberation Zapatista Army (EZLN) in the southern, indigenous state of Chiapas, rocked Mexican society with its demands for indigenous justice and cultural and political autonomy. This shifted the anthropological debate from social class, peasants, agricultural workers, to the problems of a multiethnic and multicultural Mexico and Latin America. The indigenous Zapatistas leaders transformed the perception of indigenous people as passive social actors, to intellectual and political actors, capable of profound analysis of and resistance to the asymmetry of their relations with the nation state. Today, the effects of social movements, as well as the work of indigenous anthropologists and actors continues to provide a healthy critique, not only of anthropology, but also of the system of government emerging from the Mexican revolution, and the dominant political parties of the early twenty-first century.

\section{Anthropology in Mexico}

Mexican anthropology was born out of the need to forge diverse regions and ethnicities into one nation after the Mexican Revolution (1910-1920), but has been affected by political and social movements in Mexico and Latin America - the 1968 movement, the Sandinista revolution and the Zapatista uprising. In the post-revolutionary period, anthropology was established as a key element in creating a homogenous nation, in universities, and in the state. Gamio $[21,22,23]$ and his collaborators $(1916,1972,1979)$ took the first steps in creating a legacy of integrated action-investigation in anthropology, incorporating mestizos and indigenous communities into the new nation. This was followed by the institutionalization of indigenous affairs in the state apparatus:

The federal Departamento Autónomo de Asuntos Indigenas (DAAC) was created in 1936 in response to the demands of indigenous people, with a general policy of assimilation (Comas 1964) [24]. Also in 1936, anthropology as a field was included in the IPN's (Instituto Politécnico Nacional's School of Biological Science). In 1940, the first Inter American Congress in Pátzcuaro,
Michoacán advocated integrated policies that paid lip service to the languages, cultures and dignity of the "Indian," and led to the founding of the Instituto Nacional Indigenista (INI), and anthropologist Alfonso Caso was named the first director of the National Institute of Anthropology and History (INAH). Later, the National School of Anthropology and History (ENAH) trained most anthropologists. This link between academics and the state was solidified with federal agencies (INI) and research institutions (INAH), as well as schools (IPN, ENAH) - all under the federal umbrella.

Mexican anthropology, then, was born in the state and the nation, originally had the goal of 'rescuing' the cultural heritage of the nation's ethnic groups, while forging a homogeneous nation. Among the achievements of this early Mexican anthropology were social programs designed to meet the needs of campesinos (small rural producers), in general, and of ethnic groups, in particular, and finally, of the urban poor-needs for cultural recognition, land, agricultural development, education, and health care. As part of the state apparatus, anthropologists ran many of these programs and this created a demand for anthropologists, and thus the expansion of anthropology programs in universities. These institutions initially were based on the colonializing perspective of European and North American anthropology. However, the decolonizing or nationalist bent of Mexican anthropology soon became apparent. So, Mexican social anthropology necessarily was always an applied social science focused on specific social and ethnic groups in Mexico (see also Nahmad 2014 a and b) [25,26].

In the 1950s, anthropologist Gonzalo Aguirre Beltrán [27] negotiated the complex relationship between anthropology and the state - and was roundly criticized for his theory of acculturation (1957). This criticism came to a head in 1968 in the context of international social movements and the Mexican student movement that questioned the state, the relationship between anthropology and the state, and especially the state's policy of indigenismo (Warman et al. 1972) [28]. The subsequent rise of Marxist anthropology saw indigenous peoples in the context of vertical systems of domination (a new colonialization) in new nation-states that emerged from former colonies.

This critical, perspective affected the 'dance' between anthropology and the state. This crisis raged through anthropology in Mexico, the state, research centers and universities. As Javier Guerrero [29] pointed out, students at the ENAH criticized the central position of Mexican anthropology in the discourse and policies of the state, and attacked the government: "We students are generally radical Marxists"... "who demand a) that Mexican anthropology abandon the study of indigenous communities from as fictitious isolates, b) that anthropology be separated from state politics and, c) that our science open up to theoretical currents, in particular, Marxism, that efficiently scrutinize and clearly explain social realities" (Guerrero, 1996:123).

One outcome of the 1968 movement (and Warman [28] et al.'s critique of Mexican anthropology in De eso que llaman la antropología mexicana, 1972) was the creation of a federal 
program of scholarships for indigenous intellectuals (ethnolingüistas). Thus began the movement of indigenous language speakers from the margin - as object of study - to the center, as the agent of study, bringing to the fore, among other things, their critique of the treatment of original languages in Mexico.

Many of these indigenous intellectuals play important roles in their communities, regions and states, and some of them are important actors at the national level in mobilizing for recognition of their demands. They have developed a unique, independent, critical view of the state and of anthropology. Indigenous anthropologists such as Maurilio Muñoz [30] (2009), Luis Reyes [31] (1985), Gildardo González [32] (1972), Pablo Velásquez [33] (2000), Jacinto Arias [34] (1985), Daniel Martínez [35] (1987), Miguel Sánchez [36] (2000) and others criticize mainstream anthropology for resisting their demands for recognition of cultural pluralism and political autonomy. Indigenous anthropology in Mexico today is a critical and influential voice, independent of the internal conflicts of mainstream anthropology.

One accomplishment has been the passage, in 2003, of Mexico's General Law on the Linguistic Rights of Indigenous Cultures, ${ }^{1}$ an important first step in changing policies and practices and which will undoubtedly effect the resurgence and recognition of Mexico's ethnic groups, and the most important of all: the disappearance of indigenismo ${ }^{2}$ as a key element of the theoretical toolkit of the elite members of the social and applied anthropology establishment.

Anthropology in Mexico continued to move into more independent spaces: With the opening of the School of Anthropology in the University of Veracruz and of the major in anthropology at the private Universidad Iberoamericana, the process of separation between anthropology and the federal government continued, coming to resemble the kind of academic independence found in many developed countries (see García Mora and Medina, 1983 and 1986 [2, 3]). The CISINAH (now CIESAS) anthropology research institute was formed under the national university (UNAM), an 'autonomous' institution. ${ }^{3}$ Anthropology programs were opened in state universities in Yucatán, México, Querétaro, Chihuahua, and Chiapas.

But, along with the creation of more spaces for anthropology, neoliberal policies continued to be implemented: in 1992 Article 27 of the Mexican Constitution [37] was modified, opening the door to privatization of community lands. This important change in the legal system was endorsed by anthropologist Arturo Warman, then head of the federal agency that administered this law, illustrating again the enduring and contradictory relationship between

1 See [http://www.wipo.int/wipolex/en/details.jsp?id=9302].

2 Mexico's national policy of assimilation and marginalization of indigenous peoples (see Nahmad 1995, 1990, 1988) [43, 44, 45].

3 Autonomous in this sense refers to their budget, which is a direct federal line, and not subject to modification by government ministries. anthropologists and the state in which many Mexican anthropologists defended or advocated neoliberal policies incorporated through a vertical structure of political parties, seen for example in the works of de la Peña $[38,39,40]$ (1986, 1995, 1996), Warman [41] (2003), and Viqueira and Sonnleitner [42] (2000).

Anthropologists continued their critique; the vanguard of the new anthropology were activists in new leftist political parties that opposed the PRI in the late 1980s, and the alliance between leftists and anthropologists in creating a theory and practice that, as García Mora and Medina [2] said, would "give rise to an authentic national anthropology serving the working class and inscribed in social processes as well as the currents of thinking of our times" (1983: 15). Multiple varieties of Marxism--humanistic, radical, and Soviet-style--dominated Mexican anthropological theory. Ethnological practice split in two lines that, even if they share certain theoretical bases, are separated by their approach to applying anthropology to public policies. Marxist anthropologists advocated abandoning the study of indigenous communities as separate cultural entities and concentrating on the study of social classes rather than culture. Other anthropologists--the "etnicistas"--lobbied to open new spaces for an anthropology that views ethnic groups and communities as separate groups, for example in the Autonomous Metropolitan University (UAM) and CIESAS. The greatest schism was between the many anthropologists who worked for the state, and who were considered to be apologists for it, and the Marxists. However, the contradiction between forging a critical, Marxist, anthropology while depending on the state remained.

The Zapatista (EZLN) uprising of 1994 brought more questioning of the relationship between ethnic groups and social class, as anthropologists questioned the state's commitment to pluralism, autonomy and its own agreements, for example, the San Andrés Larraínzar Agreements, ${ }^{4}$ and the resolution of the Concordia Commission and Pacification (COCOPA) of the National Chamber of Deputies. Others defended the state, for example, Warman [41] (2003:291) said "that the position of the EZLN was diminished and worn out. Over time, this debate has lost steam and is no longer a priority...." Within the same neoliberal current, anthropologists who studied the electoral process (see Viqueira and Sonnleitner, 2000 [42]), advocated electoral party democracy and the incorporation of indigenous municipalities into party politics. The result, if not the aim, was to divide and atomize indigenous pueblos, by breaking down horizontal, consensual community decision-making mechanisms and replacing them with incorporation into the vertical structure of Mexico's political parties.

In the last two decades of the twentieth century, many social anthropologists moved into (and formed) non-governmental organizations (NGOs), and became

\footnotetext{
4 See

[http://schoolsforchiapas.org/wp-content/uploads/2014/03/Indigenous-right s-and-San-Andres.pdf].
} 
intermediaries between the state and indigenous communities, campesinos (peasants) and the urban poor. ${ }^{5}$ Since much NGO funding came from the state itself or from international organizations they cannot operate as independent agents, but rather often represent the interests of international organizations or transnational corporations.

By the late twentieth century, Mexican anthropology had shifted from its post-revolutionary dependence on, and legitimizer of, the state to a position as advocate for a more democratic and pluralistic anthropology and nation. But the lines of conflict between three groups are clear: (1) anthropologists who are leftist party militants; (2) left-leaning anthropologists; and (3) anthropologists who are members of the dominant PRI (Partido Revolucionario Institucional). There is a lot of overlap, though, since most anthropologists worked, and continue to work, for the federal government, further clouding these contradictions.

From the last decade of the twentieth century through the early years of the twenty-first, many Marxist anthropologists were activists in leftist political parties, at the same time that most also worked for the state. And in 2000, many anthropologists, in order to oppose the PRI, switched their allegiance to the right-wing PAN (Partido de Acción Nacional) when they won the presidency, maintaining, through their opposition to the state, their close relationship to it. Anthropology has never achieved independence from the state.

Since 2004, the Mexican government has continued to cut funding for social programs and services, and NGOs operated by anthropologists represent, and often speak for, campesinos (peasants) and indigenous communities to the state, as well as to multinational organizations that fund many social programs without local participation.

In sum, between 1982 and 2010, the Mexican state weakened, and government agencies that supported rural and indigenous communities adopted neoliberal policies, including a sweeping land reform that opened pathways to the privatization of communal and ejidal land, closing agencies and programs and promoting the formation of NGOs. Marxist anthropologists working for the state switched allegiances from the PRI to the PAN and supported the neoliberal agenda under the guise of etnicismo (ethnicism) (see for example, Warman 2003 [41]).

\section{Anthropology in the Twenty-first Century}

Can anthropology be scientific in the study of the multiple social problems of humanity, especially in the context of the enormous cultural diversity found in nations such as Mexico?

5 Many NGOs were staffed by former government employees who lost their jobs under the trimming of the state with neoliberal reforms. Most NGOs survive from contracts with the state, making them 'free' (with no job security or benefits) government workers (see Nahmad 2016) [46].
(By diversity, we refer to the diversity of language, practices, and forms of organization, meanings and values). Humans are one universal community, but, historically and geographically specific contexts result in diverse forms - the cultures of the world. And this is the unique focus of anthropology-describing and understanding the specific adaptations of humans in societies.

Today, over seven billion people make up 200 or so states, each with multiple forms of political systems organized around maintaining unity and loyalty. Many nations are dominated by one ethnic group that dominates the other ethnic groups within their borders. These states have developed mechanisms for achieving a homogeneous national identity. Opponents of homogeneity have been classified as 'outsiders', as non-citizens, and often eliminated through acts of genocide or ethnocide (the elimination of the cultural characteristics of dominated ethnic groups). Minority ethnic groups were, and still are, dominated and by hegemonic groups who perpetuate systems of racial or cultural discrimination and domination. This scheme can be called "pluralism based on inequality", where the dominant sector aims at perpetuating their economic, political and cultural privileges, and denying them to ethnic minorities, who live in conditions of marginalization, exploitation and discrimination. Strongly centralized nations, such as Mexico, exercise vertical and unilateral power; a form of pluralism based on inequality, making demands by ethnic minorities' illegal and subject to repression.

Minority ethnic groups, in turn, resist and survive by creating defensive mechanisms that preserve their cultural, linguistic, political and religious practices and beliefs that defend their territory, at the same time that they accommodate to the legal structures of the state. The modern state, and Mexico is an example, has had to resolve the contradictions that arise from ethnic hierarchies and the resistance to them by minority groups. Anthropology's role has often been to mediate, from one side or the other, these contradictions.

The process of decolonization in nations emerging from the European and colonial metropolis has led to the recognition, in some states, of their ethnic plurality and create and structure their own multi-ethnic social and political constitutions. In Mexico, some states, unlike the national model, have begun to recognize their multiethnic and multicultural nature. In 1989, the state of Oaxaca modified its constitution by recognizing the rights of its indigenous communities and groups to maintain their consensual forms of political decision-making (usos y costumbres). Anthropologists and sociologists supported this initiative, and mediated the conflicts that arose from it, a continuation of a role that started with the First National Congress of Indigenous Peoples in Janitzio, Michoacán in 1975, through the Zapatista uprising in 1994.

Since 1970, when I began studying "Minorities and Indigenous Cultures" in the faculty of Political and Social 
Sciences at the UNAM, students have studied the structural conflicts arising from the existence of indigenous peoples in Mexico. We analyzed how indigenismo had excluded indigenous peoples from Mexico's national project. Pablo González Casanova [47] touched the heart of this concept of 'nation' when he described the concept of internal colonialism in Democracy in Mexico (1965). Anthropologists Guillermo Bonfil [48] (1996), Rodolfo Stavenhagen [49] (1980), Leonel Durán [50] (1988) took up the concept of ethnicity as a central element of our national identity, arguing for a geopolitical reordering of a plural Mexico. Marxist anthropologists disqualified our position as etnicista (prioritizing ethnicity over class), arguing that that indigenismo, as a policy of applied anthropology, is valid only as a step in assimilating Mexican ethnic groups into one social category, or class of rural proletariat, under the banner of Mexican nationality. In sum, anthropology may not be an objective science, but we struggle with how to use our methods to create accurate knowledge that can be used in the defense of indigenous peoples, their cultural rights and political autonomy.

In this essay we describe the contradictions - not so much the demise — of Western-style sociocultural anthropology in Mexico by locating its origins in the dynamic global political context. The conflicts of interest that result from the close links between academics and the state have helped maintain internal colonialism and prevent the decolonization of the indigenous peoples in Mexico. When we represent and describe the indigenous peoples of Mexico to the broader world, we are participating in a political act, an act of advocacy for their cultural and political rights, and not merely engaging in ivory-tower ruminations.

Indigenous anthropology threatens the united front that mainstream sociocultural anthropology presents, with a research agenda that does not describe the peoples of Mexico in terms of national or global domination, but continues to rely on nationalist and Eurocentric categories that have little, if any, relevance to the actual problems of development and decolonization faced by indigenous peoples.

Sociocultural anthropology today is not an "objective" theoretical discipline - pure and untouched by the biases and distortions inherent to committed or engaged political practice. Mexican anthropology was, is, and must be, an applied science. Contemporary social anthropology must support indigenous peoples in their demands for linguistic, cultural and political survival, or remain an instrument of the state and the dominant classes within it, and ultimately of internal colonialism. Mexican anthropology isn't an objective science, then, but we can carry out quality research in support of indigenous groups.

In order to fulfill our historical mandate, anthropology must now prepare to carry out participatory research with indigenous communities in their struggle for their identities and rights. For anthropology in Mexico, there remains this important task: to create a space, through our own research methods and projects, for the active participation of minority ethnicities - the original peoples of Mexico-in the decisions and policies of national society, especially insofar as these affect them. Anthropology is positioned to play a central role in the design of new strategies that replace paternalistic indigenismo with a new paradigm, one of inclusive participation of indigenous peoples in control of their natural and cultural resources. To this end a professional team in each region-including native linguists, anthropologists and archaeologists should play a vital part in planning their own destinies.

This short history of Mexican applied anthropology, its contradictory dependence on the state, and struggle to create an independent anthropological practice, calls for an anthropology that participates in research with indigenous peoples, as well as with continual evaluation of our role and work.

\section{REFERENCES}

[1] Nadel, Siegfried, A black Byzantium, Oxford University Press, London, 1942

[2] García Mora Carlos, Medina, Andrés (editores), La Quiebra Política de la Antropología Social en México: I. La impugnació,n. Universidad Nacional Autónoma de México, Instituto de Investigaciones Antropológicas, Serie Antropológica, Antropología Social: 69. México, D. F., 1983

[3] García, Mora Carlos, Medina Andrés (editores), La Quiebra Política de la Antropología Social en México: II. La polarización. Ed Universidad Nacional Autónoma de México, Instituto de Investigaciones Antropológicas, Serie Antropológica, Antropología Social: 69. México, D. F., 1986

[4] Mazrui, A. Ali, The Africans: a triple heritage, Ed. Little, Brown and Company, Canada, USA, 1986

[5] Owusu, Maxwell, La Etnología de los Etnógrafos y la Etnografía: Teoría y Práctica de la Antropología Sociocultural, Una Reconstrucción, Anuario de Etnología y Antropología Social, vol. 2, Colegio de Etnólogos y Antropólogos Sociales A.C. México, 109-134, 1989

[6] Antun, Domingo, ¿Qué es la federación Shuar?, Indianidad y Descolonización en América Latina: Documentos de la $2^{\mathrm{a}}$ Reunión de Barbados, Ed. Nueva Imagen, México, D.F., 79-83, 1979

[7] Varese, Stefano, Pueblos indígenas y globalización en el umbral del tercer milenio, Articulación de la diversidad: pluralidad étnica, autonomías y democratización en América latina, Ed. Abya-Yala, Ecuador, 123-159, 1995

[8] Riveiro,, Darcy, Gomes Mercio, Etnicidad y civilización, Articulación de la diversidad: pluralidad étnica, autonomías y democratización en América latina, Ed. Abya-Yala, Ecuador, 29-53, 1995

[9] Bonfil Batalla Guillermo, Diversidad y democracia: Un futuro necesario, Articulación de la diversidad: pluralidad étnica, autonomías y democratización en América latina, Ed. Abya-Yala, Ecuador, 9-19, 1995 
[10] Bartolomé, Miguel, Movimientos etnopolíticos y autonomías indígenas en México, Articulación de la diversidad: pluralidad étnica, autonomías y democratización en América latina, Ed. Abya-Yala, Ecuador, 227-256, 1995

[11] Grünberg, George, Los indios de la selva: nuevas estrategias y nuevas alianzas, Articulación de la diversidad: pluralidad étnica, autonomías y democratización en América latina, Ed. Abya-Yala, Ecuador, 313-321, 1995

[12] Barabas, Alicia, Iglesias y religiones: dominación colonialista y resistencia indígena, Articulación de la diversidad: pluralidad étnica, autonomías y democratización en América latina, Ed. Abya-Yala, Ecuador, 99-121, 1995

[13] Arvelo-Jiménez, Nelly, Los pueblos indígenas y la tesis ambientalista sobre el manejo global de sus recursos, Articulación de la diversidad: pluralidad étnica, autonomías y democratización en América latina, Ed. Abya-Yala, Ecuador, $81-98,1995$

[14] Emilio Mosonyi, Esteban, Amerindia e Indoamérica ante el colapso neoliberal, Articulación de la diversidad: pluralidad étnica, autonomías y democratización en América latina, Ed. Abya-Yala, Ecuador, 55-72, 1995

[15] Coelho dos Santos, Silvio, Constitución y violación de los derechos de los pueblos indígenas en el Brasil, Articulación de la diversidad: pluralidad étnica, autonomías y democratización en América latina, Ed. Abya-Yala, Ecuador, 161-174, 1995

[16] Pacheco de Oliveira, Joao, Las estadísticas sobre tierras indígenas en Brasil: una evaluación crítica, Articulación de la diversidad: pluralidad étnica, autonomías y democratización en América latina, Ed. Abya-Yala, Ecuador, 175-196, 1995

[17] Bonilla, Víctor Daniel, Itinerario de una militancia paralela: la lucha por los derechos indígenas y la lucha por la democratización en Colombia, Articulación de la diversidad: pluralidad étnica, autonomías y democratización en América latina, Ed. Abya-Yala, Ecuador, 323-345, 1995

[18] Chirif, Alberto, Movimiento indígena amazónico en Perú y cambios ocurridos en las dos últimas décadas, Articulación de la diversidad: pluralidad étnica, autonomías y democratización en América latina, Ed. Abya-Yala, Ecuador, 347-371, 1995

[19] Jaulin, Robert, La Paz Blanca: introducción al etnocidio, Tiempo Contemporáneo, Buenos Aires, Argentina, 1973

[20] Díaz Polanco, Héctor, Las Regiones Autónomas en Nicaragua, Balance de la Antropología en América Latina y el Caribe, CRIMM, UNAM, México, D.F., 543-554, 1993

[21] Gamio, Manuel, Arqueología e Indigenismo, SepSetentas, no. 24, México, 1972

[22] Gamio, Manuel, La Población del Valle de Teotihuacán, Instituto Nacional Indigenista, México, 1979

[23] Gamio, Manuel, Forjando Patria, Porrua, Mexico, 1916

[24] Comas, Juan, La Antropología Aplicada en México: Trayectoria y Antología, Instituto Indigenista Interamericano, Serie Antropología Social, no. 1, México, 1964

[25] Nahmad, Salomón, La antropología aplicada en México: Ensayos y reflexiones, CIESAS, México, 2014 a
[26] Nahmad, Salomón, Sociedad nacional, etnicidad e indigenismo, CIESAS, México, 2014 b

[27] Aguirre Beltrán, Gonzalo, El Proceso de Aculturación, No. 3 de la colección Problemas Científicos, UNAM, México, 1957

[28] Warman, Arturo et. al. De eso que llaman antropología mexicana, Escuela Nacional de Antropologia e Historia, Comité de Publicaciones de los Alumnos, México, D.F, 1972

[29] Guerrero, Javier, El Desencuentro del Marxismo y la Antropología en México 1970-1990, La Historia de la Antropología en México, Plaza y Valdés, Universidad Iberoamericana, INI, México, 1996

[30] Muñoz Basilio, Maurilio, Fuentes para la historia del indigenismo en México: Diario de campo de Maurilio Muñoz en la cuenca del Papaloapan (1957-1959), Comisión Nacional para el Desarrollo de los Pueblos Indígenas, México, 2009

[31] Reyes García, Luís, Programa de formación profesional de etnolingüistas, Archivo Guillermo Bonfil Batalla Funcionario, CIESAS, Programa de Etnolingüística, 22 hojas, México, 1985

[32] González Ramos, Gildardo, Los coras, Instituto Nacional Indigenista, Secretaría de Educación Pública, México, 1972

[33] Velásquez Gallardo, Pablo, La hechicería en Charapan, Michoacán, Universidad Michoacana de San Nicolás de Hidalgo, Instituto de Investigaciones Históricas, México, 2000

[34] Arias Jacinto, San Pedro Chenalho: algo de su historia, cuentos y costumbres, Gobierno del Estado de Chiapas, México, 1985

[35] Martínez Daniel, Tu'ukni'mit ayuuk Jyujkyajtï’ïn, Religión Ayuuk de Tamazulapan, tesis de Licenciatura, Inédito, Tlaxcala, 1987

[36] Sánchez Álvarez, Miguel, Los tzotziles-tzeltales y su relación con la fauna silvestre, Gobierno del Estado de Chiapas, Consejo Estatal para la Cultura y las Artes de Chiapas, Chiapas, 2000

[37] México, Constitución Política de los Estados Unidos Mexicanos, México, 1992

[38] De la Peña, Guillermo, Poder local, poder regional: Perspectivas Socioantropológicas, Poder Local, Poder Regional, Colegio de México, CEMCA, México, 27-50, 1986

[39] De la Peña, Guillermo, La Ciudadanía Étnica y la Construcción de los Indios en el México Contemporáneo, Revista Internacional de Filosofía Política, no. 6, Diciembre, 116-140, 1995

[40] De la Peña, Guillermo, Nacionales y extranjeros en la historia de la antropología mexicana, La historia de la antropología en México: Fuentes y transmisión, México, Universidad Iberoamericana, INI, Plaza y Valdés, México, 41-81, 1996

[41] Warman, Arturo, Los indios mexicanos en el umbral del milenio, Fondo de Cultura Económica, México, 2003

[42] Viqueira, Juan Pedro, S. Willibald, Democracia en tierras indígenas: Las elecciones en los altos de Chiapas, CIESAS, Colegio de México, IFE, México, 2000 
[43] Nahmad, Salomón, Violencia, violación de derechos humanos, democracia y crisis económica en México: Su impacto en los pueblos indígenas, Articulación de la diversidad: pluralidad étnica, autonomías y democratización en América latina, Abya-Yala, Ecuador, 257-312, 1995

[44] Nahmad, Salomón, Reinvidicaciones étnicas y política indigenista en México, Indianismo e indigenismo en América, Alianza Universidad, Madrid, 251-270, 1990

[45] Nahmad, Salomón, Cap. X. Indigenismo oficial y luchas indígenas en México, Derecho indígena y derechos humanos en América Latina, IIDH, COLMEX, México, 299-315, 1988

[46] Nahmad, Salomón, Riflessioni e analisi storiche e attuali sulle ONG e sulle società civili in Messico e a Oaxaca in sostituzione delle politiche sociali della Rivoluzione messicana, Los Otros Welfare Esperienze storiche e proposte di sicurezza sociale nel Messico contemporaneo (secoli XIX e XX), Fondazione Eni Enrico Mattei, Italia, 299-327, 2016

[47] González Casanova, Pablo, La Democracia en México, Era, México, 1965

[48] Bonfil Batalla, Guillermo, México profundo: reclaiming a civilization, University of Texas, Austin, USA, 1996

[49] Stavenhagen, Rodolfo, Problemas étnicos y campesinos: ensayos, Instituto Nacional Indigenista, Secretaría de Desarrollo Social, México, 1980

[50] Duran Solis, Leonel, El proyecto nacional y las culturas populares una aproximación, México: 75 años de revolución, vol. IV, Educación, cultura y comunicación, Fondo de Cultura Económica, México, 1988

i A previous version of this paper was presented at the $73^{\text {rd }}$ annual meetings of the Society for Applied Anthropology, session on Natural Resource Distribution and Development in the 21st Century. March 19-23, 2013. 